\title{
Collaborative Consumption
}

\section{Business Model Opportunities and Barriers for Fashion Libraries}

Gjerdrum Pedersen, Esben Rahbek; Netter, Sarah

Document Version

Final published version

Publication date:

2013

License

CC BY-NC-ND

Citation for published version (APA):

Gjerdrum Pedersen, E. R., \& Netter, S. (2013). Collaborative Consumption: Business Model Opportunities and Barriers for Fashion Libraries. Center for Corporate Social Responsibility, CBS.

Link to publication in CBS Research Portal

\section{General rights}

Copyright and moral rights for the publications made accessible in the public portal are retained by the authors and/or other copyright owners and it is a condition of accessing publications that users recognise and abide by the legal requirements associated with these rights.

Take down policy

If you believe that this document breaches copyright please contact us (research.lib@cbs.dk) providing details, and we will remove access to the work immediately and investigate your claim. 


\section{BS N. COPENHAGEN}

HANDELSHOJSKOLEN

\section{Collaborative Consumption: Business Model Opportunities and Barriers for Fashion Libraries}

Esben Rahbek Gjerdrum Pedersen, Copenhagen Business School Sarah Netter, Copenhagen Business School

Published by

CBS Center for Corporate Social Responsibility

Porcelænshaven 18

DK - 2000 Frederiksberg 


\title{
Collaborative Consumption: Business Model Opportunities and Barriers for Fashion Libraries
}

\author{
Esben Rahbek Gjerdrum Pedersen \& Sarah Netter
}

\section{Abstract}

- Purpose: The purpose of this paper is to explore barriers and opportunities for business models based on the ideas of collaborative consumption within the fashion industry.

- Design/methodology/approach: The analysis is based on a multiple-case study of Scandinavian fashion libraries - a new, clothes-sharing concept that has emerged as a fashion niche within the last decade.

- Findings: It is concluded that fashion libraries offers interesting perspectives, e.g. by allowing people to experiment with styles without having to pay the full cost and becoming a meeting place for young designers and end consumers. However, at present fashion libraries remain a small-scale phenomenon with difficulties reaching the mainstream market, not least due to limited financial and human resources as well as conventional fashion consumption patterns.

- Research limitations/implications: The study is limited to the new phenomenon of fashion libraries and does not cover other types of collaborative consumption within the fashion industry (Swap-parties, etc.).

- Originality/value: The paper is one of the first attempts to examine new business models of collaborative consumption in general and the fashion library concept in particular. The study contributes to the discussions of whether and how fashion sharing and collaboration holds promise as a viable business model and as a means to promote sustainability.

\section{Introduction}

The idea of collaborative consumption has gained widespread popularity since the Rachel Botsman and Roo Rogers popularized the term in the book "What's Mine is Yours" (2010). Collaborative consumption is ultimately about people sharing and collaborating to meet certain needs, whether it concerns transportation, accommodation, land etc. Prominent examples include AirBnB (space sharing) and ZipCar (car sharing) though the term collaborative consumption covers practically all types of products and services where people share excess resources. In 2010, Time listed collaborative consumption as one of "10 Ideas That Will Change the World" (Walsh, 2011).

The idea of collaborative consumption has yet to take hold in the mainstream fashion industry. However, this may be about to change as we are currently seeing a mushrooming of initiatives based around ideas of sharing and community. Examples include online services like ThredUp, 
which resells kidswear, Swapstyle, which enables people to swap fashion worldwide, and local Swishing parties where people share clothes from their own wardrobes. There are good reasons to pay attention to these initiatives and explore ways to scale-up these burgeoning business models. First, collaborative consumption is expected to have significant business potential for the fashion industry. The US market value for used children's clothes alone is said to be between USD 1-3 billion (Botsman and Rogers, 2010). What's more, collaborative consumption reduces overconsumption - one of the root challenges facing sustainability efforts in the fashion industry (Kozlowski et al., 2012). Today, around 30\% of the clothes UK households have in their wardrobe have not been worn for a year or longer, representing an estimated value of $£ 30$ billion (WRAP, 2012). Promoting redistribution of unused garments will therefore benefit buyers and sellers as well as the environment.

The purpose of this paper is to explore barriers and opportunities for developing a business based on the ideas of collaborative consumption in the fashion industry. As we will demonstrate in the next sections, a number of internal and external factors imply that new, fashion business models based on collaborative consumption often have difficulties in moving from the margins to the mainstream of the fashion industry. To limit the scope of the paper, focus is on the relatively new fashion library concept, which is a subscription-based service that allows people to share wardrobes. Within the last few years, fashion libraries have popped up in a number of Nordic cities including Stockholm, Copenhagen, Malmö, Umeå, Gothenburg, Lund, and Helsinki.

This paper makes a contribution to the existing fashion marketing and management literature by being one of few scholarly attempts to examine new business models of collaborative consumption. So far, fashion scholars and practitioners have paid only scant attention to collaborative consumption even though this phenomenon is experiencing significant growth (Botsman and Rogers, 2010). Moreover, to the authors' knowledge, this paper is the first study that systematically examines the clothes library concept from a business-model perspective. The fashion library concept is both relevant as a business opportunity based on the idea of collaborative consumption and as a means to promote a more efficient use of clothing that will lower the environmental footprint of fashion manufacturing and consumption. Clothes-leasing has previous been identified as an opportunity for reducing the demand of materials which in turn will have a positive environmental impact (Allwood et al., 2006). However, little is known about how different types of clothes-sharing systems can work as a business model and a sustainability strategy.

The remainder of the paper is structured as follows. The paper begins with a short presentation of the business model concept that has served as the conceptual framework for analyzing the data. By going through each business model component, it will be possible to describe in detail the business architecture of clothes libraries. The presentation of the business model literature is followed by a description of methodology, which provides details about data selection, collection and analysis. The subsequent analysis describes similarities and differences in the structure of clothes libraries and highlights barriers and opportunities for making this new concept a sustainable business model. Based on the findings from the analysis, the conclusion and discussion section reflects on potential avenues for scaling up and mainstreaming the clothes library business model. 


\section{A Business Model Perspective on Collaborative Consumption}

It is becoming increasingly popular to talk about business models. From 1995, more than 1,000 articles in peer-reviewed academic journals have dealt with the topic (Zott et al., 2011). In the beginning, the business model concept was especially used in relation to e-business but has since spread to other fields and is now a popular metaphor for portraying different business architectures (Wüstenhagen and Boehnke, 2008). To give a concrete example, Gillette has become the epitome of the "blades-and-razor" business model where a company sells a basic product cheap but makes money on people using it (Johnson et al. 2008; Teece, 2010). Other business models include 'Freemium' (free standard product and premium for advanced offerings), and the 'Long Tail' (selling large quantities of multiple niche products) (Osterwalder and Pigneur, 2010).

Although the business model concept is widely used, it remains ill-defined (George and Bock, 2011). The term 'business model' is a multi-dimensional construct that has been used by researchers from different disciplines and with different interests (Zott et al., 2011). As there have been several attempts to break down the business model concept into different, interrelated subcomponents, numerous definitions of this term now exist (see e.g. Zott et al. 2011; Morris et al., 2005; Johnson and Suskewicz, 2009). Despite its definitional shortcomings, there is a consensus among business-model literature that the concept indicates how a company, alone and as partner, creates value from its activities (Zott et al., 2011; Chesbrough, 2007; Teece, 2010). In the words of Zott and Amit (2007, p. 181): "A business model elucidates how an organization is linked to external stakeholders, and how it engages in economic exchanges with them to create value for all exchange partners".

Recognizing the centrality of value creation in most business model thinking, we will define the concept in line with Osterwalder and Pigneur (2010, p. 14), who characterize business models broadly as: "(...) the rationale of how an organization creates, delivers, and captures value". Moreover, Osterwalder and Pigneur's (2010) popular business model canvas will serve as an analytical framework to examine the clothes library concept (See Figure 1). In short, the business model canvas is made up of nine different elements central to the understanding of how a company creates, delivers, and captures value. Below, we have tried to show how each component of the business model canvas is relevant for fashion companies addressing sustainability: 
The Business Model Canvas

Designed by:

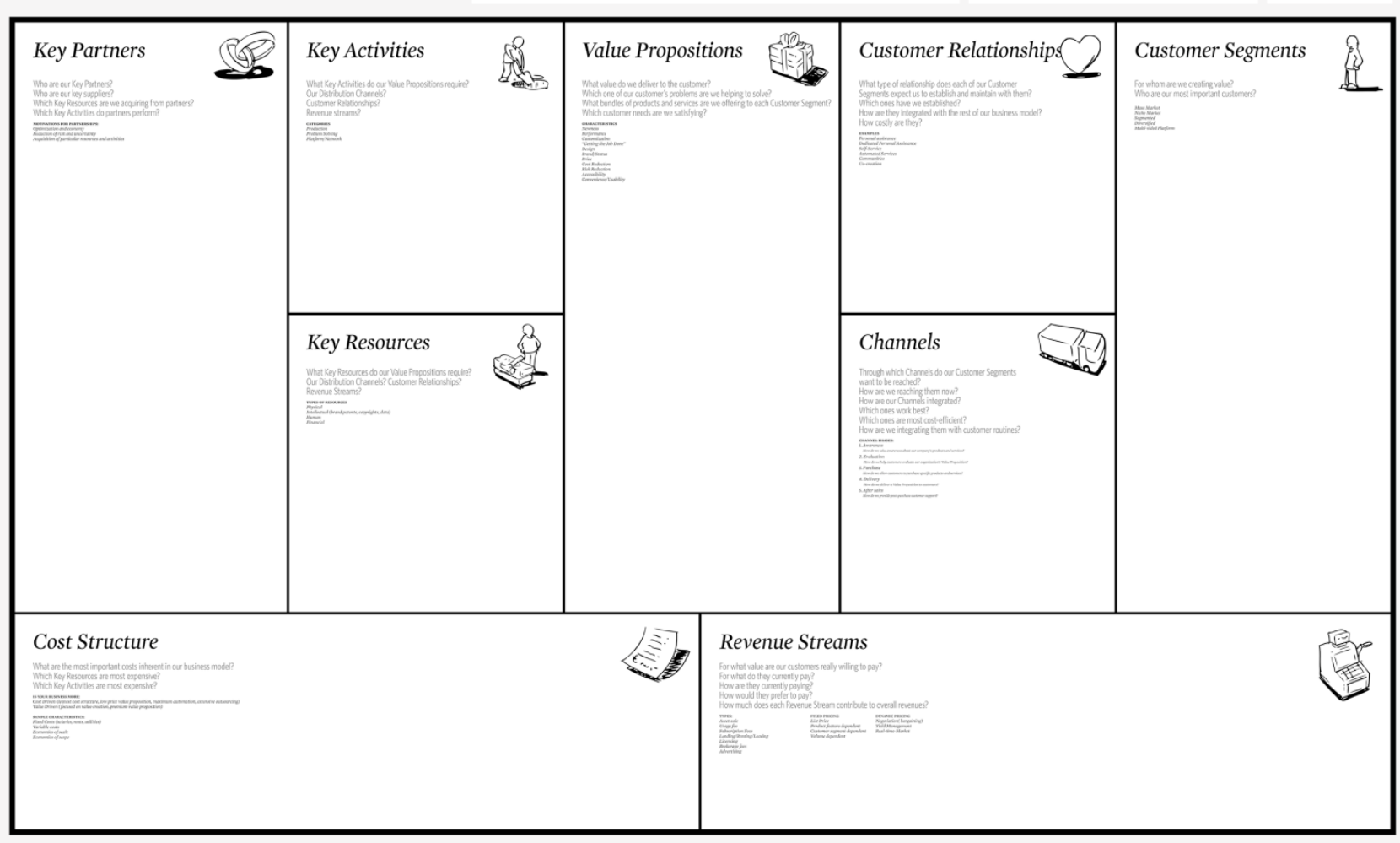

www.businessmodelgeneration.com

(웅ㅇㅇ (2)(1) (1)

Figure 1: The Business Model Canvas

Source: http://www.businessmodelgeneration.com/canvas

- Customer segments. This business model component concerns the characteristics of the clients served by the company (Osterwalder and Pigneur, 2010). For instance, a number of fashion companies now build their brand on sustainability initiatives to target the 'green' and 'ethical' consumer. As an example, the UK fashion company, People Tree, brands itself explicitly as a pioneer in sustainable/fair trade fashion. However, realizing the niche role of sustainable fashion, some mainstream brands are instead trying to reach the green segment by building sustainability into more conventional 'fast fashion' business model.

- Value Proposition. The term 'value proposition' indicates how a customer benefits from choosing a company's products and services (Osterwalder and Pigneur, 2010). For instance, slow fashion companies address the needs of consumers looking for alternatives to massproduced standard goods that are manufactured in anonymous, global supply chains with little or no consideration of their social and environmental impacts (Fletcher, 2011). Likewise, the secondhand industry creates value for customers recognizing that e.g. children grow out of their clothes before the end of the items' functional life.

- Channels. Companies reach customers with their products and services through different channels (brick and mortar stores, franchise stores, online stores etc.) (Osterwalder and Pigneur, 2010). The online market for secondhand clothes is a notable example of a channel that extends product lifetime while also potentially lowering over-consumption. The US 
outdoor company, Patagonia, for instance, has partnered with E-bay to promote product reuse as part of their efforts to lower the environmental footprint of its business activities. Similarly, the Swedish kidswear company Polarn o. Pyret, has begun offering secondhand shopping on their website.

- Customer Relationships. Companies establish and develop relationships with customers in many different ways, e.g. depending on whether their business model is based on selfservice or personal assistance (Osterwalder and Pigneur, 2010). For example, hosting swap parties can both serve as a means to promote product reuse and build customer relationships. Likewise, offering repair and recycling services can be a means to establish links with customers, generate new revenue streams, and address sustainability all at the same time (WRAP, 2012). One example of this would be the Norwegian outdoor company, Norrøna, which has established a repair service center at their flagship store in Oslo.

- Revenue Streams. Some companies generate revenue by selling products to customers, while others base their business on service arrangements, leasing options, subscription payments, advertising etc. (Osterwalder and Pigneur, 2010). To give a few examples: the German company, Lütte leihen, offers clothes leasing for babies and infants, and the household appliance company, Electrolux, has tested a pay-per-wash system as an alternative to the conventional asset sale of washing machines - a system which may also hold sustainability potentials by incentivizing responsible washing behavior (Black, 2012).

- Key Resources. Companies hold different combinations of tangible and intangible resources (buildings, knowhow, brands etc.), which help them create value for customers and strengthen their competitive position (Osterwalder and Pigneur, 2010). For instance, a number of companies now experiment with alternatives to conventional cotton and polyester. The Icelandic company, Atlantic Leather, for instance, has specialized in transforming waste materials from the fishing industry into fashion products.

- Key Activities. Companies need to undertake a number of key activities in order to serve customers before, during and after sales (Osterwalder and Pigneur, 2010). From a sustainability perspective, instilling a sense of sustainability among designers is considered key because the environmental impact of a product is determined at least partly by its design (Kozlowski et al., 2012). Likewise, frontline sales and marketing staff need the right training and education to guide customers toward sustainable alternatives.

- Key Partnerships. Companies do not operate in isolation but are dependent on the contributions of various business partners (suppliers, logistics providers etc.) (Osterwalder and Pigneur, 2010). From a sustainability perspective, a number of fashion take-back partnerships have recently emerged. Patagonia has partnered with E-Bay, Marks \& Spencer has joined forces with Oxfam, and H\&M has collaborated with I:CO. A number of companies have also begun providing a variety of products and services to support fashion companies' sustainability efforts. For instance, the Danish company, Norman Hangers, provides an environmental-friendly alternative to the traditional plastic hangers used in fashion retail stores across the world.

- Cost Structure. While companies must pay attention to the costs associated with running a business model, sustainability makes increasingly good business sense from a cost perspective. Real prices of raw materials have increased with 147 percent since year 2000 and can be expected to rise even further in the future (ENV, 2013). As an example of cost- 
saving sustainability initiatives, Levi's has introduced Water $<$ Less jeans which dramatically reduces water use during the manufacturing process. Similarly, Puma's Clever Little Bag is a good example of how some companies are developing smarter packaging solutions that reduce costs and environmental effects.

\section{Methodology}

The following analysis is based on semi-structured interviews with founders/co-founders and representatives from four Scandinavian clothes library initiatives. Table 1 provides a short description of the fashion libraries. The interviewees were asked to describe how they approached each component of the business model and reflect on potential improvements and alternatives that could help expand the fashion library concept. The qualitative interview method is seen as a preferential alternative since the study is explorative in nature and addresses a relatively new field that has, so far, received limited scholarly attention. In addition to interviews, secondary information was obtained from the clothes libraries and other external sources. The data collection took place in 2013 and is part of the MISTRA Future Fashion research program.

\section{Table 1: Short Description of the Fashion Libraries}

\begin{tabular}{|l|l|}
\hline Resecond: http://resecond.com/ & $\begin{array}{l}\text { Located on Copenhagen's Jægersborggade, } \\
\text { Resecond was established in September 2012. } \\
\text { Its approximately } 200 \text { members can swap their } \\
\text { own dresses with a current inventory of some } \\
300 \text { pieces. Membership is issued on a half-year } \\
\text { basis, and costs } 600 \text { DKK. When signing up to } \\
\text { become a member, customers have to bring } \\
\text { dresses they would like to contribute to the } \\
\text { communal wardrobe. For now, Resecond does } \\
\text { not generate any profit for its owner. }\end{array}$ \\
\hline $\begin{array}{l}\text { Lånegarderoben: } \\
\text { http://www.lanegarderoben.se/ }\end{array}$ & $\begin{array}{l}\text { Lånegarderoben was founded in 2009 during a } \\
\text { festival in a small Swedish provincial town and } \\
\text { today is permanently based in the Stockholm } \\
\text { suburb Midsommarkransen. Lånegarderobens' } \\
90 \text { members can choose from approx. 750 items, } \\
\text { which are sponsored from various fashion } \\
\text { brands, young upcoming designers and a few } \\
\text { individuals involved in the library. } \\
\text { Becoming a member of Lånegarderoben costs } \\
600 \text { SEK for six months, which allows members } \\
\text { to borrow up to three items at a time for up to } \\
\text { four weeks. Lånegarderoben is run by a } \\
\text { handful of volunteers. }\end{array}$ \\
\hline $\begin{array}{l}\text { Helsinki Fashion Library: } \\
\text { http://www.nopsatravels.com/en/nopsa- }\end{array}$ \\
$\begin{array}{l}\text { Thelsinki Fashion Library was established } \\
\text { in } 2011 \text { when the two founders rented an empty } \\
\text { office space in central Helsinki. Today, the }\end{array}$ \\
\hline
\end{tabular}




\begin{tabular}{|l|l|}
\hline & $\begin{array}{l}\text { fashion library has approximately } 100 \text { members } \\
\text { who have access to a shared wardrobe with } \\
\text { approx. } 750 \text { items, mostly made up of clothes } \\
\text { from local Finnish fashion designers. The } \\
\text { Helsinki Fashion Library offers three kinds of } \\
\text { six-month memberships, ranging from } 160 \text { to } \\
460 \text { EUR. Helsinki Fashion Library is run } \\
\text { voluntarily by its two founders and has one } \\
\text { paid employee. }\end{array}$ \\
\hline Klädoteket, Malmö: http://kladoteket.se/ & $\begin{array}{l}\text { Klädoteket was established in 2010 by four } \\
\text { students. Today the fashion library located a } \\
\text { little outside Malmö city centre is run by two } \\
\text { women on a voluntary basis. The fashion } \\
\text { library has approximately 290 members who } \\
\text { can borrow as many items as they want for } \\
\text { three weeks with the possibility of extending } \\
\text { rental for another three weeks. Currently, } \\
\text { members can choose from approximately 2700 } \\
\text { items. The clothes are mainly donated but } \\
\text { people also have the possibility to share their } \\
\text { wardrobe in Klädoteket for a limited period of } \\
\text { time. Klädoteket has recently suspended } \\
\text { membership fees and is now free to join. }\end{array}$ \\
\hline
\end{tabular}

\section{Analysis of Findings}

The customer segment of the clothes libraries is mainly females between 25 and 35 years old and most of the members live relatively close by, i.e. within ten minutes' travel. Members living further away are restricted by travel times and the limited opening hours of clothes libraries. In all cases, men only make up a small segment of clothing library users. Motives for becoming a member and making use of one's membership are varied. While for some, frequent use of the library appears to be driven by access to a variety of clothes at a relatively low cost, for others, in cases where library prices are comparatively higher, frequent use pertains to making the most of one's membership. Others appear to be especially driven by unifying their interest in fashion while simultaneously making a change, reducing consumption, and ultimately making a sustainable contribution. Some members display great understanding and involvement with the concept of collaborative consumption, and are typically also members of food cooperatives.

One of the key value propositions put forth by the libraries is that they give members the freedom to play with different styles and be creative without having to pay full price. The libraries provide a creative playground without the costs, risks, and burden of ownership. As the Helsinki Fashion Library suggests, having access to a shared wardrobe allows members to experiment with their 
style, so they do not end up with the conventional black dress but rather move toward something more colorful. In a similar vein, because they do not have to pay full price, Klädoteket members frequently leave the Klädoteket clothes library with more extravagant, vibrant clothing. In addition to providing access to expensive designer pieces and exposing members to a wider variety of apparel, fashion libraries also offer members a break from their usual consumption routines. In the words of the Helsinki Fashion Library, some people are tired of conventional consumption patterns, of always buying new clothes and throwing away old ones. The idea here is to provide options for renewing one's wardrobe without contributing to ever-increasing consumption cycles. Finally, the history of the clothing is an important part of the value proposition and elements of clothes story-telling is an essential element of communication in several fashion libraries. For instance, members in Resecond write small stories about the history of the garments on handwritten tags, and in the case of Lånegarderoben, members are encouraged to take pictures of themselves in the borrowed garments and upload them to the fashion library's Facebook page.

The main channel for members to share clothes is the physical spaces of the libraries. Besides their fixed physical stores, the majority of libraries engage in additional events, which allow them to have pop-up libraries in connection with festivals or for instance during the national clothingswap day. Klädoteket has extended their activities by partnering up with a local library and a community activity center, though, so far, no opportunities for reserving and exchanging clothes online exist. Resecond, however, is in the process of developing a smartphone App, which will allow members to swap their clothes directly online. In general, revenue channels represent a challenge for fashion libraries. With the exception of Resecond, which is located on a popular street in Copenhagen, all fashion libraries suffer from unfavorable locations which means that potential members often do not just drop by unless they know exactly where to find the libraries. To give a few examples, the Helsinki Fashion Library is located in a rented storage facility inside a big office building where the main doors are closed at 17.00, which makes it difficult for members to coordinate working hours with opening hours. In the case of Klädoteket, the fashion library is located 10 minutes' biking distance from the Malmö city center and thus demands extra effort from potential members. Klädoteket considers its less than optimal location as a significant barrier to further growth.

Establishing good customer relationships is a key element of the fashion library concept. According to Resecond, members appreciate the social factor that comes with exchanging clothes in a physical place, being able to see someone else happy in your own clothes, and partaking in the story of the clothes. In a similar vein, Helsinki Fashion Library has one big fitting room where people can try clothes together and help each other find garments that suit their needs and style. Nurturing customer relationships is done in the physical store and through social media. With regards to the former, dialogue in the physical store is seen as crucial for making members feel comfortable and think of the library as their second wardrobe. Moreover, the fashion libraries host various events, including sewing workshops, parties, receptions, or pop-up stores, and events, where members can buy some of the fashion library clothes which are in low demand or swap their own clothes with other members. With regards to the latter, social media (mainly Facebook) is considered by all libraries as a powerful tool for building customer relationships. The site is in most cases updated every time the shop is open, informing about new events, incoming garments or 
donations, pictures from users etc. In the experience of Klädoteket, the more active they are on Facebook, the more people actually go to the shop during opening hours.

The main revenue stream for most fashion libraries stems from membership fees. Only limited income is generated from other sources (e.g. penalty fees, events, sponsorships etc.). The Helsinki Fashion Library has three kinds of bi-annual membership fees, ranging from 160 EUR to 460 EUR, with different privileges when it comes to how many items members can borrow and for how long. Becoming a member of Lånegarderoben costs 600 SEK for six months, which gives members the right to borrow up to three items at a time for up to four weeks. Resecond membership is also held on a half-year basis and costs 600 DKK. In contrast to Lånegarderoben, members do not have to return their swapped clothes. When signing up to become a member, new members have to bring dresses they would like to contribute to the wardrobe. In return, they can take home and equal amount of dresses or swapping vouchers, in case they do not find anything. Klädoteket has recently made the decision to make its service free of charge for members. Today, there is only a small penalty fee for damaging clothes or not handing them in on time. In addition to penalty fees, Klädoteket has received minor financial support from the municipality and an educational institution, which enables them to pay the rent and cover fixed costs. The decision to have a free service is based on the conviction that this will enable Klädoteket to make the service available to more people and thereby spread the message that there is no reason to constantly buy new clothing when there is already so much available.

The clothing collection a library can offer its members is obviously a key resource for clothes libraries. Building a collection of clothes sufficient to attract members is the main challenge when establishing a new fashion library. But, most libraries in this study did not report difficulties in acquiring new garments and many receive new items weekly from designers, retailers and/or members. All libraries have the possibility to influence their collection by choosing which designers or retailers to approach directly, or by selecting specific items brought for donation by individual members and staff. In general, the composition of a library's collection is highly dependent on the style and philosophy of that fashion library. Resecond only offers dresses, ranging from newer, high-end brands to vintage pieces, and the decision as to which items should enter the shared wardrobe ultimately depends on the founders' personal evaluation. The Helsinki Fashion Library and Lånegarderoben are also selective when it comes to the style and quality of the garments. In addition, Lånegarderoben requires that fashion brands have a Corporate Social Responsibility (CSR) profile if they want to donate clothes to the library. Klädoteket seems to be the least restrictive fashion library when it comes to accepting new items and explicitly aims at broadening its collection to suit a wide variety of styles, people, and occasions.

Human resources are also of paramount importance for fashion libraries, which are mostly run on a voluntary basis and all highly dependent on the enthusiasm, drive, and commitment of a few key people. Limited human resources, however, is also one of main threats to the current fashion library concept, as it puts limitations on the services offered to the members. For instance, lack of staff results in limited opening hours, which may collide with the working hours of members. Moreover, limited human resources make the fashion libraries very vulnerable to situations in which key personnel decide to leave the organization. As an example, it has been challenging for 
people to work voluntarily in Lånegarderoben in addition to a normal job, family obligations etc. The vulnerable character of some of the fashion libraries also makes it questionable if they will be able to scale up operations, set up new libraries, and otherwise develop the concept to make it more sustainable in the long run. To cope with the human resource problem, Klädoteket has recently thought about involving members more directly in the operations of the fashion library. Essentially, interested members are expected to work every now and then in the library to avoid dependency on a few especially active individuals - a cooperative model well-known in the food retail industry. However, it is too early to say if this change in the fashion library concept will be successful.

The key activities of a fashion library bear similarities to a traditional fashion retail store. In opening hours, there must be staff to arrange the clothes, clean up the library, serve clients, and handle borrowing and returns. Key activities outside opening hours consist of registering new wardrobe entries, making small repairs, checking member accounts to make sure that everyone has paid, checking to ensure pieces have been returned on time, and sending notifications to members whose accounts have expired. In order to further its community character and spread the word, a key activity for fashion libraries is to engage members and promote the library on Facebook and other social media. Recently, there has been a lot of hype around fashion libraries, which means that the libraries are frequently contacted by the media and by people interested in the concept or in starting their own fashion library. The everyday work of running a fashion library requires human resources, and in short supply developing and growing the organization can present a challenge. Klädoteket testifies that the efforts required to attract new members - registering new garments, improving IT-systems, planning special events, developing communication materials (flyers, web posts etc.) - takes a significant amount of time and, consequently, demands greater human resources.

Members are both upstream and downstream partners for fashion libraries, since members are often also suppliers who donate part of their own wardrobes to the fashion library. However, some fashion libraries have also established partnerships with well-known fashion brands and various designers that donate part of their collections to the library either permanently or for a limited period of time. For instance, a major sponsor of Lånegarderoben is the Stockholm based fashion company Filippa K, which has provided approximately 100 items to the library. According to Lånegarderoben, Filippa K considers this partnership as an integrated part of their CSR work, which also includes exploring new forms of sustainable consumption. Another example is Helsinki Fashion Library, which collaborates with young, local designers, who are often eager to partner, since they have difficulties in accessing the market through mainstream fashion retailers. By donating clothes to the fashion library, designers gain market access and the opportunity to test collections among members who also have the possibility of buying garments directly from the designers. Another type of partnership is the collaboration with organizations that help spread the fashion library concept and solve problems associated with unfavorable geographical locations (see above). For instance, Klädoteket collaborates with a library and a community activity center where they gain access to a group of users who are familiar with the concept of collaboration and sharing. The library offers literature, music, films etc. for free and the community activity center enables people to borrow tools, computers, sewing machines, etc. In the future, Klädoteket hopes 
to establish relationships with other, similar organizations not based on buying and selling and where sharing materials is common practice among members.

The cost structure reflects the voluntary nature of most fashion libraries. The main costs of running a fashion library concern fixed costs such as rent, electricity and insurance. In three out of the four fashion libraries surveyed, all work is performed on a voluntary basis. Only the Helsinki Fashion Library has the means to employ staff in addition to the voluntary work put in by the founders. However, at least three fashion libraries aim at turning the libraries into a commercial business, which would allow them to move away from reliance on volunteer work. Klädoteket is the only fashion library that does not perceive a significant need for external funding or for returning to a business model based on membership fees.

\section{Conclusion and Discussion: Scaling up Collaborative Fashion Consumption?}

Fashion libraries and other initiatives based on the collaborative consumption model are popping up all over the world. Klädoteket, for instance, was recently asked for advice by a group in Mexico considering initiating a similar type of clothes-sharing organization. However, the evidence from this study also indicates that fashion libraries still remain a niche activity, driven by enthusiastic entrepreneurs working on a voluntary basis. Fashion libraries have received widespread media attention, which, so far, seems to exceed the actual impact of these libraries on the fashion landscape. On average, fashion libraries maintain only 100-300 members. It is therefore worth considering potential avenues for turning the fashion library concept into a more mainstream and commercially sustainable business model. Based on the findings from this study, we have concluded that future fashion libraries will have to reflect on some of the following questions:

- Who are the customers? The fashion libraries are membership-based and target consumers open to alternatives to conventional shopping. However, there may be other relevant customers to the services provided by fashion libraries. The evidence from the Helsinki Fashion Library indicates that small, local designers often have difficulties accessing the market through mainstream retailers. Therefore, it may be possible to build an alternative fashion library concept with the active participation of collectives or smaller suppliers (designers), who pay a small fee for promoting their work for a limited period of time to a relevant audience.

- Where are the profitable customers? Having customers is not enough. In order to build a sustainable business, customers also have to be profitable for the company. According to Klädoteket, they recommend that fashion libraries target people who are open to new concepts and experience a clear need. As an example, high school and university students are young, care a lot about their looks, have limited financial resources, and are generally aware of sustainability challenges. Therefore, this group constitutes an interesting market segment for fashion libraries. The question remains, however, if students are at present a sufficiently profitable market segment for running a fashion library. International examples 
such as the Albright Fashion Library and Bib + Tuck indicate that there may be other and potentially more profitable market niches for fashion libraries.

- What is the value proposition? A successful fashion library concept necessitates that the company solves a problem for customers in one way or another. Experience from some of the fashion libraries indicates that style and variety rather than sustainability may be the key drivers for members, i.e. allowing people to experiment with styles and try different designer clothes without having to pay the full price. A key benefit of fashion libraries seems to be that members get an opportunity to experiment with styles and looks without having to pay full price. Therefore, the question is whether fashion libraries should be marketed on the basis of style rather than sustainability. According to Botsman \& Rogers (2010, p. 74), it is actually rare that sustainability is the main driver for establishing a collaborative consumption initiative. In most cases, sustainability can instead be conceptualized as a positive side effect of collaborative initiatives.

- How to generate revenue: Fashion libraries could benefit from a broader palette of revenue channels. Today, the money for running fashion libraries stems mainly from membership fees, but it may be possible to generate money from e.g. designers (see above), advertising, sponsorships, consultancy, web shops, etc. Moreover, the fashion libraries studied are all $100 \%$ membership-based initiatives. However, it may be possible to combine this model with a conventional, sales-based business concept, making it part of the offering to the customer to choose between buying and borrowing fashion products.

- Which collections to choose: Fashion libraries can't stay open long if the clothes available are not attractive to its members. Therefore, fashion libraries may benefit from upgrading their collections, e.g. through partnerships with fashion brands or small designers, in order to create more value for members. Moreover, some items should perhaps be excluded from the collections due to low demand. It may also be worthwhile focusing only on womenswear since men only constitute a small percentage of members. Special niches for men (e.g. designer jeans or sportswear) can be considered at a later stage when the market acceptance of fashion libraries has increased.

- Picking the right partners: Partnerships may be a way forward to improve the long-term survival and growth of fashion libraries. As seen above, Klädoteket has established partnerships with libraries, cultural institutions, and student organizations in order to spread the fashion library concept. Likewise, the Helsinki Fashion Library has approached young designers who often struggle to get their collections to market. Partnerships may therefore pose a mutually-beneficial way to reach customers with a sharing service that offers exclusive, cutting-edge fashion collections. Likewise, fashion libraries may establish partnerships with major fashion brands to get early market feedback on new collections by offering these clothing lines in fashion libraries.

- How to cope with limited resources: All fashion libraries studied try to keep costs as low as possible but still maintain many of the same costs as traditional fashion retailers (rent, 
salaries, IT, electricity, inventory etc.). To offset these expenses and achieve balance, fashion libraries are forced to cut down on membership services (limited opening hours) and rewards to staff and owners (who mostly work voluntarily). Today, the survival of most fashion libraries is dependent on the commitment of a few entrepreneurs and the loyalty of a small group of members. Locations tend to be unattractive as they are out of reach of mainstream fashion consumers. These factors, among others, make the current fashion library concept vulnerable. As discussed above, it is therefore important that fashion libraries work on generating new sources of revenue to better serve existing members and attract new ones.

- Need for a new mindset? An obvious barrier outside the realm of control for the fashion libraries is recognition of the fact that changes in dominant consumer mindsets take time. The message of collaborative consumption is that the current ownership culture has to be replaced by sharing and collaboration, but we have yet to see this transformation in actual fashion consumption. Therefore, fashion libraries may have to focus on niche markets where there is a clear need and customers are open to the concept of sharing and collaboration. As mentioned in the analysis, libraries such as Klädoteket often attract users that are familiar with and supportive of the concept of collaboration and sharing.

Innovation is often considered a precondition for competition in today's global marketplace. The ability to rethink dominant business logic can be considered a precondition for a company to survive and prosper. However, it is not always advantageous to be a pioneer in a new market with a new product. It may well be the 'fast second' company successful in scaling up and consolidating the new market with a dominant design or format that prospers in the end (Markides and Geroski, 2004). Fashion libraries represent a new and innovative concept that breaks with the dominant fashion business model based on buying and selling. As such, fashion libraries continue to experience a number of challenges related to limited resources and the existing ownership culture. It is still unclear whether the fashion libraries studied will be able to prosper and survive going ahead. Regardless, new start-ups and more established brands may glean important lessons from the fashion library experience, and begin to build offerings to consumers with the collaborative consumption model in mind - thereby carving the way for collaborative consumption to become common practice within the fashion industry. 


\section{References}

Allwood, J. M., Laursen, S. E., de Rodriguez, C. M., and Bocken, N. M. P (2006), “Well dressed?", University of Cambridge Institute for Manufacturing, Cambridge, UK.

Black, S. (2012), The Sustainable Fashion Handbook, Thames \& Hudson, London.

Botsman, R. and Rogers, R. (2010), What's Mine is Yours, Collins, London.

Chesbrough, H., (2007), "Business model innovation: it's not just about technology anymore", Strategy E Leadership, Vol. 35 No. 6, pp. 12-17.

ENV, 2013. Veje til en bæredygtig fremtid - Idékatalog fra Tænketank om bæredygtigt forbrug og grønne forretningsmodeller, Danish Environmental Protection Agency (ENV), http://www2.mst.dk/download/Milj\%C3\%B8tek/idekatalog_opslag.pdf

George, G. and Bock, A. J., (2011), "The Business Model in Practice and its Implications for Entrepreneurship Research", Entrepreneurship Theory and Practice, Vol. 35 No. 1, pp. 83-111.

Hamel, G. (2000), Leading the Revolution, Harvard Business School Press, Boston, Massachusetts.

Johnson, M. W., Christensen, C. M., and Kagermann, H., (2008), "Reinventing Your Business Model", Harvard Business Review, Vol. 86 No. 12, pp. 51-59.

Johnson, M. W. and Suskewicz, J., (2009), "How to Jump-Start the Clean-Tech Economy", Harvard Business Review, Vol. 87 No. 11, pp. 52-60.

Kozlowski, A., Bardecki, M., and Searcy, C., (2012), "Environmental Impacts in the Fashion Industry: A Life-cycle and Stakeholder Framework", Journal of Corporate Citizenship, Vol. 45 (Spring 2012), pp. 17-36.

Markides, C. and Geroski, P. A., (2004), "Racing to be Second: Conquering the Industries of the Future", Business Strategy Review, Vol. 15 No. 4, pp. 25-31.

Morris, M., Schindehutte, M., and Allen, J., (2005), "The entrepreneur's business model: toward a unified perspective", Journal of Business Research, Vol. 58 No. 6, pp. 726-735.

Osterwalder, A. and Pigneur, Y. (2010), Business Model Generation, John Wiley \& Sons, Inc., Hobroken, New Jersey.

Teece, D. J., (2010), "Business Models, Business Strategy and Innovation", Long Range Planning, Vol. 43 No. 2-3, pp. 172-194.

WRAP (2012), Valuing our Clothes, Waste \& Resources Action Programme (WRAP), www.wrap.org.uk/clothing.

Wüstenhagen, R. and Boehnke, J., (2008), "Business Models of Sustainable Energy", In: Tukker, A., Charter, M., Vezzoli, C., Stø, E., and Andersen, M. M. (Eds), System Innovation for Sustainability: Perspectives on Radical Changes to Sustainable Consumption and Production, Greenleaf Publishing, Sheffield, UK, pp. 70-79.

Zott, C. and Amit, R., (2007), "Business Model Design and the Performance of Entrepreneurial Firms", Organization Science, Vol. 18 No. 2, pp. 181-199.

Zott, C., Amit, R., and Massa, L., (2011), "The Business Model: Recent Developments and Future Research", Journal of Management, Vol. 37 No. 4, pp. 1019-1042. 